DOI: $10.19195 / 2300-7249.41 .1 .3$

MAŁGORZATA CZURYK

ORCID: 0000-0003-0362-3791

Uniwersytet Warmińsko-Mazurski w Olsztynie

JAROSŁAW KOSTRUBIEC

ORCID: 0000-0003-1379-9846

Uniwersytet Marii Curie-Skłodowskiej w Lublinie

\title{
The legal status of local self-government in the field of public security
}

The local self-government was established through the process of devolution of the public administration, as entities designed to meet the needs of local and regional communities. These include security needs which are the most crucial public needs. All the three levels of local self-government fulfil public security tasks, but these vary in degree of intensity, scope and reach. They are very often of a complementary nature, not independent, even though some scope of autonomy was vested in this kind of government. Security needs are not addressed based on the principle of competition but through efficiency and cooperation. Public security is too important to allow local government structures to compete with each other in this area, at the cost of quality and effectiveness in addressing such needs, and therefore the lawmakers have organised this sphere so as to replace this rivalry with mutual support in such activities.

Security is essentially to be ensured by the executive power. ${ }^{1}$ Regardless of the tier of administration, tasks in this field must be carried out uninterruptedly ${ }^{2}$ and the local self-government has also a role to play in ensuring security. In this respect,

${ }^{1}$ K. Dunaj, "Kompetencje Prezydenta RP w sprawach obronności i bezpieczeństwa państwa", [in:] Rozważania nad problemami wspótczesnych społeczeństw demokratycznych, Płock 2010, p. 83 ff.; K. Dunaj, "Zadania i kompetencje Rady Ministrów w sferze obronności i bezpieczeństwa państwa", [in:] Wspótczesne bezpieczeństwo narodowe i międzynarodowe. Uwarunkowania, relacje, zależności, vol. 1, eds. M. Kubiak, M. Minkina, Siedlce 2011, p. $13 \mathrm{ff}$.

2 M. Karpiuk, "Konstytucyjna właściwość Sejmu w zakresie bezpieczeństwa państwa”, Studia Iuridica Lublinensia 2017, no. 4, p. 10. 
it should be stressed that actors within the security system must comply with the rule of law principle as one of the general principles of a democratic state. ${ }^{3}$

The freedom of operation of local self-government units entails responsibility for the quality and scope of services being provided. ${ }^{4}$ This also applies to public security as one of the elementary needs ${ }^{5}$ and also as part of the self-governance administrative policy. ${ }^{6}$ It should be stressed that the pursuit to ensure security is one of the basic responsibilities of the local self-government. ${ }^{7}$ The local self-government is unable to resolve all local problems on its own, nor can it independently create the conditions for its own operation. ${ }^{8}$ The problem that cannot be coped with by the local self-government is providing security, as it is often not able to ensure it with limited means and resources held by it.

A special involvement of local government is required during states of emergency proclaimed due to situations of higher threat. ${ }^{9}$ If the municipality, district or regional government bodies are not efficient enough in the performance of their public tasks or in the implementation of the martial law provisions, ${ }^{10}$

${ }^{3}$ M. Czuryk, "Prawne podstawy bezpieczeństwa narodowego", [in:] Podstawy bezpieczeństwa wspótczesnego państwa (podmiotu). Implikacje, ed. J. Pawłowski, Warszawa 2015, p. 533; G. Kryszeń, K. Prokop, Aksjologia polskiej konstytucji, Warszawa 2017, pp. 121-122. The principle of democratic state governed by the rule of law entails the fact that law is a fundamental determinant of the functioning of the state, also in security matters, M. Karpiuk, "Prawne podstawy bezpieczeństwa", [in:] Podstawowe kategorie bezpieczeństwa narodowego, ed. A. Żukowski et al., Olsztyn 2015, p. 65.

${ }^{4}$ M. Karpiuk, Samorzad terytorialny a państwo. Prawne instrumenty nadzoru nad samorzadem gminnym, Lublin 2008, p. 14. See also M. Karpiuk, "Zasady regulujące funkcjonowanie samorządu terytorialnego w Polsce", [in:] Samorzad terytorialny w Polsce i na Ukrainie, ed. M. Karpiuk, Poznań-Kijów 2013, pp. 66-68.

5 Security constitutes the value which is both desirable and necessary, M. Karpiuk, "Bezpieczeństwo jako instytucja konstytucyjna. Zarys problematyki", [in:] Wybrane problemy bezpieczeństwa globalnego po zimnej wojnie, ed. W. Gizicki, Lublin 2015, p. 11. On the issue of public security, see more in: M. Karpiuk, N. Szczęch, Bezpieczeństwo narodowe i międzynarodowe, Olsztyn 2017, pp. 86-93.

6 P. Szreniawski, Prawno-administracyjne zagadnienia ustrojowej polityki administracyjnej, Toruń 2012, p. 56.

7 M. Karpiuk, J. Kostrubiec, Rechtsstatus der territorialen Selbstverwaltung in Polen, Olsztyn 2017, p. 65. For more on responsibilities of the public administration, see: P. Szreniawski, Obowiazek w prawie administracyjnym, Lublin 2014.

${ }^{8}$ P. Szreniawski, "Samorząd terytorialny a kultura polityczna", [in:] M. Karpiuk, Samorząd terytorialny w Polsce i na Ukrainie, Poznań-Kijów 2013, p. 20.

9 See: K. Prokop, Stany nadzwyczajne w Konstytucji Rzeczypospolitej Polskiej z dnia 2 kwietnia 1997 r., Białystok 2005, pp. 154-156. The participation of local self-government bodies in ensuring security is related in many countries to the process of constitutionalisation of local government, K. Dunaj, "Konstytucyjna regulacja samorządu terytorialnego w wybranych państwach Unii Europejskiej”, [in:] Samorząd terytorialny w procesie integracji europejskiej, ed. K. Dunaj, Łomża 2015, p. $7 \mathrm{ff}$.

${ }^{10}$ Martial law is declared by the President of Poland by way of an ordinance, upon a request of the Council of Ministers, M. Karpiuk, "Prezydent Rzeczypospolitej Polskiej jako organ stojący na straży bezpieczeństwa państwa”, Zeszyty Naukowe AON 2009, no. 3, p. 396. 
the President of the Council of Ministers, upon a request from the competent voivode (provincial governor) may suspend these bodies until the martial law is abolished, or for a definite period, and establish the compulsory administration exercised by a government commissioner. The government commissioner is appointed and dismissed by the President of the Council of Ministers at the request of the voivode. Upon the day of his appointment, he takes over the exercise of responsibilities and powers of the suspended bodies of the municipality, district or regional government. The state of suspension of the local self-government bodies ceases on the date specified by the President of the Council of Ministers, and by virtue of the law upon the abolition of the martial law. ${ }^{11}$ The legislature introduces here, for the supervision of local self-government authorities, a non-constitutional criterion of the lack of sufficient effectiveness. The only criterion allowing interference with the sphere of freedom of local self-government, including in the field of public security, is the violation of the principle of legality by municipal, district or regional government bodies. Even a threat due to which martial law is introduced, thus an external threat to the national security, including that caused by acts of terrorism or activities in the cyberspace, an armed assault on the territory of the Republic of Poland, as well as a commitment to a common defence against aggression where that commitment is the result of an international agreement, does not entitle the central government to restrict the freedom of a decentralised structure if this structure does not violate the law.

The term "sufficient effectiveness" is spacious enough to actually give the President of the Council of Ministers a considerable extent of discretion in the case of suspension of the local self-government bodies, which is inadmissible from the point of view of the principle of decentralisation of public administration. ${ }^{12}$

The solution applicable to the state of emergency, similar to that of martial law, is also constitutionally questionable. According to the legislature, if the municipality, district or regional government bodies are not efficient enough in the

11 Article 14 of the Act of 29 August 2002 on Martial Law and the Competences of the Commander-in-Chief of the Armed Forces and the Rules of his Subordination to the Constitutional Authorities of the Republic of Poland (consolidated text: Journal of Laws of 2017, item 1932). See also: M. Czuryk, "Podstawy normatywne wprowadzenia, obowiązywania oraz zniesienia stanu wojennego", [in:] Prawo obronne Rzeczypospolitej Polskiej w zarysie, eds. M. Czuryk, W. Kitler, Warszawa 2014, p. 277; M. Karpiuk, "Normatywne uwarunkowania stanu wojennego i wyjątkowego", Studia Prawnicze i Administracyjne 2015, no. 3, p. 6; M. Czuryk, "Właściwość Rady Ministrów oraz Prezesa Rady Ministrów w zakresie obronności, bezpieczeństwa i porządku publicznego", [in:] System Bezpieczeństwa Narodowego, vol. 3, ed. M. Karpiuk, Olsztyn 2017, pp. 85-86. On the issue of the general supervision over the performance by the local self-government of the defence responsibilities exercised by the Minister of National Defence under martial law, see: M. Karpiuk, "Zadania i kompetencje Ministra Obrony Narodowej w czasie stanów nadzwyczajnych — ujęcie normatywne", [in:] Minister Obrony Narodowej i Naczelny Dowódca Sit Zbrojnych w systemie kierowania bezpieczeństwem narodowym RP. Wybrane problemy, ed. W. Kitler, Warszawa 2013, p. 96.

12 M. Karpiuk, Ksztaltowanie się instytucji stanów nadzwyczajnych w Polsce, Warszawa 2013, p. 205. 
performance of their public tasks or in the implementation of the state of emergency provisions, the President of the Council of Ministers, upon a request from the competent voivode (provincial governor) may suspend these bodies until the state of emergency is abolished, or for a definite period and establish the compulsory administration exercised by a government commissioner. The government commissioner is appointed and dismissed by the President of the Council of Ministers at the request of the voivode. Upon the day of appointment, the government commissioner takes over the exercise of responsibilities and powers of the suspended bodies of the municipality, district or regional government. The state of suspension of the local self-government bodies ceases on the date specified by the President of the Council of Ministers, and by virtue of law upon the abolition of the state of emergency. ${ }^{13}$ In this case, the means of supervision will be the suspension of the body, the President of the Council of Ministers being authorised to suspend both bodies at the same time, or alternatively either the executive body or the legislative body. Due to the introduction of the government commissioner, the status of local self-government in the field of public security in the case of martial law and the state of emergency is clearly limited. Then the responsibilities and powers covering the response to the threat and determining the declaration of an extraordinary state are to be taken over by the central government administration, namely by the government commissioner appointed by the President of the Council of Ministers.

During a state of natural disaster, ${ }^{14}$ actions aimed at the prevention or elimination of the consequences of the natural disaster are managed by a one-man body of the local government: 1) mayor (village head, town mayor, president of the city) - if the state of natural disaster was declared only for the municipality area; 2) district governor (starosta) - if the state of natural disaster was declared for the territory of more than one municipality forming part of the district (powiat). ${ }^{15}$ Only the Marshal of the Voivodeship was not endowed with such powers, as they were granted to the voivode.

13 Article 12 of the Act of 21 June 2002 on State of Emergency (consolidated text: Journal of Laws of 2017, item 1928). See also: M. Karpiuk, "Działanie organów administracji publicznej w czasie stanów nadzwyczajnych", Studia Prawnicze i Administracyjne 2015, no. 4, p. 36. The President of the Council of Ministers will arbitrarily assess whether the bodies of local selfgovernment are "sufficiently effective" in their actions or not; M. Karpiuk, Zadania i kompetencje zespolonej administracji rzadowej w sferze bezpieczeństwa narodowego Rzeczypospolitej Polskiej. Aspekty materialne i formalne, Warszawa 2013, p. 169.

14 The Polish Constitution of 1997 remains one of few European constitutions which contain regulations on the state of natural disaster, K. Prokop, "Wokół problematyki stanu klęski żywiołowej w konstytucjach państw europejskich", [in:] Studia i szkice z prawa publicznego. Księga dla uczczenia pamięci Profesora Eugeniusza Smoktunowicza, ed. A. Nowakowski, Rzeszów 2008, pp. 124-143.

15 Article 8 of the Act of 18 April 2002 on the State of Natural Disaster (consolidated text: Journal of Laws of 2017, item 1897): hereinafter: ASND. 
The state of natural disaster obliges the local government to take appropriate follow-up actions regarding the effects of the disaster - both to prevent them and to remedy them.

During a natural disaster, in order to prevent or eliminate the consequences of the natural disaster, the executive body of the municipality, pursuant to Article 9 paragraph 2 ASND, may issue binding instructions to bodies of auxiliary units, heads of organisational units established by the municipality, heads of fire protection units operating in the municipal area and heads of those organisational units which had been temporarily handed over by the competent authorities to the executive body of the municipality and ordered to perform the tasks in the municipal area. ${ }^{16}$ The performance of this type of action is determined by the necessity to eliminate as quickly as possible the effects of a natural disaster or prevent these effects. Due to the necessity of quick and sometimes immediate preventive or follow-up action, very often there is a need to issue binding instructions to entities which can support such actions.

During a state of natural disaster, in order to prevent or remedy the consequences of the natural disaster, the mayor (village head, town mayor, president of a city which does not form a separate district), if the state of natural disaster is declared for the territory of more than one municipality, is reporting to the district governor (starosta). This subordination is provided for in Article 9 paragraph 4 ASND. The principle of subordination of the municipality executive body to the district board chairman contradicts the mutual independence of individual units of self-government, the principle of decentralisation and the autonomy of local self-government. Therefore, it is difficult to accept such a solution not only as being in line with the idea of local self-government but also as constitutionally legitimate.

In the event of inability to manage or improper management of activities carried out to prevent or remedy the consequences of a natural disaster, the voivode on his own initiative, or at the request of the district governor (starosta), may suspend the powers of the mayor (village head, town mayor, city president) concerning the issue of binding instructions to bodies of auxiliary units, heads of organisational units established by the municipality, heads of fire protection units operating in the municipal area and heads of those organisational units which had been temporarily handed over by the competent authorities to the executive body of the municipality and ordered to perform the tasks in the municipal area, or to request the heads of other organisational units to perform activities as necessary to prevent or remedy the consequences of the natural disaster and appoint a representative in charge

16 See also M. Karpiuk, "Zasady działania samorządu lokalnego w czasie stanu klęski żywiołowej”, Annales Universitatis Mariae Curie-Skłodowska. Ius 2014, no. 2, p. 55; W. Kitler, M. Czuryk, M. Karpiuk, eds., Aspekty prawne bezpieczeństwa narodowego RP. Część ogólna, Warszawa 2013, pp. 189-190. 
of those activities. ${ }^{17}$ These voivode's powers result from Article 9 paragraph 5 ASND. ${ }^{18}$ The criterion to justify the sovereign interference in the area of freedom of the municipal government is the inability to manage or improper management of actions relating to the consequences of a natural disaster. It is a non-constitutional criterion which must not be introduced by the ordinary legislature .

Similar arrangements, as in the case of a municipal executive body, also apply to a district governor. As regards the management of activities carried out in the district area to prevent or remedy the consequences of a natural disaster, the district governor (starosta) may issue binding instructions to the mayors (village heads, town mayors, city presidents), bodies of auxiliary units, heads of organisational units established by the municipality, heads of fire protection units operating in the municipal area, and heads of organisational units temporarily transferred by the competent authorities at his disposal and directed to perform tasks in the district area. The district governor's power to issue binding instructions is based on Article 10 paragraph 2 ASND. On the other hand, Article 10 paragraph 5 ASND provides for the voivode suspending the above-mentioned district governor's powers and appointing a representative to be in charge of the activities to prevent or remedy the consequences of a natural disaster in the event of inability to manage or improper management of these activities. The suspension of powers takes place upon the appointment of the representative. As in the case of municipality, also in the case of a district (powiat), the criterion which justifies the interference, namely the inability to manage or improper management of the activities to prevent or remedy the consequences of a natural disaster, is constitutionally inadmissible. It is also unacceptable for the district governor (starosta) to issue binding instructions to mayors (village heads, town mayors, presidents of cities which are not separate districts). Both these local government entities (municipality and district) are characterised by autonomy permitting independent operation of bodies of those entities and thus the implementation of their own policies, including security policies.

The regional government has been excluded from the process of managing the activities to prevent or remedy the effects of a natural disaster, as the management in this field in the regional area has been entrusted to the voivode. ${ }^{19}$ During a state of natural disaster, activities carried out to prevent or remedy the conse-

17 Zob. K. Prokop, "Stany nadzwyczajne w Konstytucji RP", [in:] Aspekty prawne bezpieczeństwa narodowego RP. Część ogólna, eds. W. Kitler, M. Czuryk, M. Karpiuk, Warszawa 2013, pp. 189-190.

18 In Article 9 paragraph 5 ASND, the legislature allows cooperation as an extraordinary measure, M. Karpiuk, "Zadania i kompetencje samorządu terytorialnego w czasie stanów nadzwyczajnych", [in:] Zadania i kompetencje samorzadu terytorialnego w zakresie porządku publicznego i bezpieczeństwa obywateli, obronności oraz ochrony przeciwpożarowej i przeciwpowodziowej, eds. M. Karpiuk, M. Mazuryk, I. Wieczorek, Łódź 2017, p. 101.

19 M. Czuryk, "Zadania organów jednostek samorządu terytorialnego w stanie klęski żywiołowej”, Zeszyty Naukowe AON 2009, no. 3, p. 407. 
quences of a natural disaster are managed by the voivode, if the state of natural disaster is declared for an area of more than one district belonging to the province (voivodeship). These powers result from Article 8 paragraph 3 ASND. Activities of the regional government concerning the prevention of or remedying the consequences of natural disasters will only be of a supportive nature, since the managerial functions are explicitly attributed by the legislature to the bodies clearly listed in Article 8 ASND, which do not include the regional government authorities.

The legislature has provided for, in Article 10 paragraph 4 ASND, the district governor reporting to the voivode with respect to managing the activities aimed at preventing or remedying the consequences of a natural disaster, during a natural disaster, when the state of natural disaster was declared for the area of more than one district belonging to a province, or an area of more than one province. The principle of subordination applies in the central government administration, not in the local self-government, and even matters of public security do not justify the introduction of such a relationship between the central government administration and the local self-government.

The basic requirement for the operation of the public authority in the context of an emergency state is that these actions are proportionate to the threat. In view of the above, the public body may not impose such socially severe measures which are not indispensable, if the same objective is met by means of milder measures. ${ }^{20}$

Public security activities are also carried out as part of crisis management. The matters of crisis management in local government have been entrusted to one-man bodies. ${ }^{21}$

The body which is competent for crisis management matters in the district area is the district governor acting as the chairman of the district board. His responsibilities in this area include: 1) the management of the monitoring, planning, response to and remedying the consequences of threats in the district area; 2) the performance of tasks in the field of civilian planning; 3 ) the management, organising, and conducting training, drills and training in the field of crisis management; 4) the implementation of projects arising from the operational plan of the functioning of districts and cities forming separate districts; 5) the preventing, counteracting and remedying of the effects of terrorist events; 6) the cooperation with the head of the Internal Security Agency (Agencja Bezpieczeństwa Wewnętrznego, ABW) in counteracting, prevention and remedying of effects of terrorist events; 6) the organisation and implementation of responsibilities in the field of critical infra-

20 M. Czuryk, "Podstawy prawne bezpieczeństwa narodowego w stanie kryzysu i wojny", Roczniki Nauk Spolecznych 2013, no. 3, p. 70.

21 Thus, the scholarly opinion formulated a view about the principle of one-man management within the crisis management system, J. Radwanowicz-Wanczewska, K. Prokop, "Organizacja systemu zarządzania kryzysowego w Polsce”, [in:] Dziesięć lat reformy ustrojowej administracji publicznej w Polsce. Ogólnopolska konferencja naukowa, Łańcut, 12-14 czerwca 2008 r., eds. J. Parchomiuk, B. Ulijasz, E. Kruk, Warszawa 2009, pp. 784-785. 
structure protection..$^{22}$ In a district, the district governor's responsibility covers the managing of crisis management activities, and the legislature has delegated the tasks in this regard to him, not to the district management board. This is due to the need for quick decision-making in the situation of a public security threat, when the board would have to convene a meeting to take the decision, which could intensify the negative effects of the threat.

The crisis management responsibilities are exercised by the district governor with the assistance of central administration entities integrated within the district administration, district government organisational units, or the district crisis management team. Due to the complexity of such responsibilities, and their importance for the district community, the district governor's auxiliary staff was extended to support his operations in crisis management matters.

District crisis management centres are also to be formed, which, according to Article 18 paragraph number $2 \mathrm{ACM}$, are supposed to ensure information flow for crisis management purposes. Therefore, it is another entity assisting in the work of the district governor in this regard.

At the municipal level, the competent authority in crisis management matters is the village head, town mayor, or city president whose responsibilities include: 1) the management of the monitoring, planning, response to and remedying the consequences of threats in the municipality area; 2) the performance of tasks in the field of civilian planning; 3 ) the management, organising, and conducting training, drills and exercises in the field of crisis management; 4) the implementation of projects arising from the operational plan of the functioning of municipalities; 5) the preventing, counteracting and remedying of the effects of terrorist events; 6) the cooperation with the head of the Internal Security Agency (Agencja Bezpieczeństwa Wewnętrznego, ABW) in counteracting, prevention and remedying of effects of terrorist events; 7) the organisation and implementation of responsibilities in the field of critical infrastructure protection. These tasks result from Article 19 paragraph $2 \mathrm{ACM}^{23}$ In municipalities, similarly to the district level, matters of crisis management are managed single-handedly, and this function is exercised by the executive body of the municipality, which can react on an

22 Article 17 paragraphs 1-2 of the Act of 26 April 2007 on Crisis Management (consolidated text: Journal of Laws of 2017, item 209, as amended), hereinafter: ACM. See also: M. Karpiuk, "Terenowe organy administracji publicznej właściwe w sprawach zarządzania kryzysowego", Annales Universitatis Mariae Curie-Skłodowska. Ius 2014, no. 1, p. 81; M. Czuryk et al., Bezpieczeństwo państwa. Zagadnienia prawne i administracyjne, Olsztyn 2016, p. 235.

23 See also: M. Karpiuk, Miejsce samorzadu terytorialnego $w$ przestrzeni bezpieczeństwa narodowego, Warszawa 2014, p. 171. By adopting the concept of one-man body with attributes of power exercised in the field of crisis management, the legislature did not waive the powers of the municipal council in this respect, although the powers of the legislative municipal body is considerably smaller as compared to its executive body, M. Czuryk et al., Prawo zarzadzania kryzysowego. Zarys systemu, Olsztyn 2016, p. 89. 
ongoing basis to the situation in the municipal area, including the threat dynamics, which makes it possible to take appropriate preventive or follow-up measures.

The municipal executive body exercises the managerial function, but also the planning and organising functions in the sphere of crisis management. ${ }^{24}$

Tasks in the field of crisis management are not performed by the municipal executive body alone but with the help of the organisational unit of the municipal office competent for crisis management matters, the municipal crisis management team or the municipal crisis management centre, if such a centre was established. From the point of view of the effectiveness of their implementation, these tasks need to be handled in a professional, not accidental, way, both in the personal and material aspects.

Activities for public security may cover the option of establishing local regulations by the local self-government in response to the threat concerned.

Order regulations constitute an important category of local law, they can be issued in extraordinary circumstances, when negative effects of human activity on a given area, or natural phenomena that threaten the community occur, or in the case of a considerable probability of such consequences. ${ }^{25}$ For public order regulations, their unique character and special place in the system of universally binding law sources should be stressed. ${ }^{26}$

In matters not regulated by separate acts or other generally applicable regulations, the municipal council may issue public order regulations if necessary to protect the life or health of citizens and to ensure public order, peace and security. ${ }^{27} \mathrm{An}$ analysis of Article 40 paragraph 3 AMG suggests that in order to establish specific norms in the form of public order regulations, two conditions must occur simultaneously. First of all, the matter to be governed by the regulation cannot be regulated in other generally applicable provisions, and secondly, the introduction of specific norms must be justified by the protection of values referred to in that

${ }^{24}$ M. Czuryk, "Zadania i kompetencje samorządu terytorialnego w zakresie zarządzania kryzysowego", [in:] Zadania i kompetencje samorzadu terytorialnego w zakresie porzadku publicznego i bezpieczeństwa obywateli, obronności oraz ochrony przeciwpożarowej i przeciwpowodziowej, eds. M. Karpiuk, M. Mazuryk, I. Wieczorek, Łódź 2017, p. 51.

25 M. Czuryk, "Stanowienie aktów prawa miejscowego przez organy samorządu terytorialnego szczebla lokalnego i regionalnego", [in:] Akty normatywne i administracyjne, ed. M. Karpiuk, Warszawa 2009, p. 130.

${ }^{26}$ M. Czuryk, "Akty prawa miejscowego organów rządowej administracji niezespolonej”, [in:] Niezespolona administracja rzadowa, eds. M. Czuryk, M. Karpiuk, J. Kostrubiec, Warszawa 2011, p. 266.

27 Article 40 paragraph 3 of the Act of 8 March 1990 on Municipal Government (consolidated text: Journal of Laws of 2017, item 1875, as amended), hereinafter: AMG. See also M. Karpiuk, "Status prawny organów samorządu terytorialnego w sferze bezpieczeństwa publicznego", [in:] Prawo bezpieczeństwa publicznego, eds. M. Karpiuk, K. Walczuk, Warszawa 2013, pp. 109-110; M. Karpiuk, J. Kostrubiec, Rechtsstatus der territorialen Selbstverwaltung..., pp. 96-97. 
provision. ${ }^{28}$ The authorisation for the municipal council under Article 40 paragraph 3 AMG cannot be construed by extensive interpretation, which means that public order regulations may be issued only in exceptional circumstances, strictly defined by the regulation concerned. ${ }^{29}$ The "unregulated scope" can be referred to under Article 40 paragraph 3 AMG only if there are no other regulations in the system of universally binding law, which allow for the elimination of the developments noticed by the municipality, which are undesirable according to this provision, ${ }^{30}$ while "necessary" means indispensable, imperative, critical. ${ }^{31}$ The reason for this, that is public security, makes it possible to introduce restrictions, orders or prohibitions of specific behaviour by means of public order regulations, if such matters have not already been regulated in the generally applicable provisions. Although there is no statutory definition of public security, which makes it difficult to interpret, it cannot be perceived arbitrarily. It is forbidden to arbitrarily restrict civil liberties by means of public order regulations, treating public safety as a prerequisite for extensive interference.

The fact that the legislature provided for in Article 40 paragraph 3 AMG the qualified preconditions shows the uniqueness of public order regulations in the sense that they are issued only in special circumstances, when it is necessary to protect in such a form values important for the local community, such as public order and security. ${ }^{32}$

Due to the scope of impact of public order regulations on third-party entities, they must be adopted only for the protection of a qualified interest. The degree of their severity to the addressee determines the application of such norms only as a last resort, when other legal means fail to adequately secure an important interest. ${ }^{33}$

In adopting public order regulations, the municipal council must bear in mind the conditions set out in the statutes. One cannot use them to fill gaps in national legislation or to reduce the risks of nationwide importance. ${ }^{34}$ The municipal council's powers to adopt public order regulations may not be used for the ongoing

28 Judgement of the Regional Administrative Court of 18 October 2011, II SA/Wr 501/11, LEX no. 1103075.

29 Judgement of the Regional Administrative Court of 8 December 2010, IV SA/Po 793/10, LEX no. 821207.

30 Judgement of the Supreme Administrative Court of 11 July 2006, II GSK 68/06, LEX no. 267157.

31 Judgement of the Regional Administrative Court of 8 December 2010, IV SA/Po 793/10, LEX no. 821207.

32 M. Karpiuk, K. Prokop, P. Sobczyk, Ograniczenie korzystania z wolności i praw człowieka i obywatela ze względu na bezpieczeństwo państwa i porządek publiczny, Siedlce 2017, p. 180.

33 M. Karpiuk, "Przepisy porządkowe jako szczególny rodzaj prawa miejscowego", Studia Iuridica Lublinensia 2015, no. 4, p. 21.

34 Judgement of the Regional Administrative Court of 17 February 2011, II SA/Go 26/11, LEX no. 795082 . 
administration of the area concerned, but only to counteract actual threats to the values set out in Article 40 paragraph 3 AMG. ${ }^{35}$

According to Article 41 paragraphs 2-3 AMG, in a case of urgency, public order regulations may be issued by the mayor (village, head, town mayor, city president), in the form of an order, which is subject to approval at the earliest session of the municipal council. It becomes ineffective in the event of refusal of approval or failure to submit to approval at the earliest session of the municipal council. The failure to approve such an order must be regarded tantamount to refusal of approval and consequently lead to such legal effects as refusal of approval, or failure to submit the order for approval at the earliest session. ${ }^{36}$ As a rule, the municipal council adopts public order regulations in the form of a resolution, but only by way of an exception it can be issued by the executive body of the municipality by means of an order. In this particular case, the three conditions must be cumulatively met: 1) the matters to be regulated are not reflected in the generally binding law; 2) the regulation is necessary to protect the life or health of citizens and to ensure public order, peace and security; 3 ) there is a case of urgency. A case of urgency is when the municipal council cannot convene a meeting, and due to the threat, its escalation or spreading the negative effects of this threat, it is necessary to immediately issue the public order regulations.

Article 41 paragraph 4 AMG provides for that in the event of failure to submit for approval or a refusal to approve the order, the municipal council sets a time limit for it to become ineffective. This rule emphasizes the role of the municipal council as a legislative authority which ultimately decides on the validity of the mayor's order.

Due to the nature of the threat which determines the introduction of the public order regulations and their impact on neighbouring units of local government, Article 41 paragraph 5 AMG introduced the obligation to send them to mayors of the neighbouring municipalities and the district governor (starosta) of the district in which the municipality is located, the day after their adoption. This allows residents of these municipalities to learn about the content of these regulations, as they may also apply to them if they stay in the municipality concerned, as well as to prepare the neighbouring municipalities for possible threats.

Public order regulations may also be issued for the district area. To the extent not regulated by separate acts or other generally binding law, where it is particularly justified, a district council may issue district public order regulations, if it is necessary to protect the life, health or property of citizens, the natural environment or for the provision of public order, peace and security, as far as these causes occur

35 Judgement of the Regional Administrative Court of 11 March 2010, II SA/Go 72/10, LEX no. 599180.

36 Decision of the Supreme Administrative Court of 12 July 2011, II OSK 1336/11, ONSAiWSA 2012, no. 2, item 26 . 
in an area covering more than one municipality. ${ }^{37}$ Public security is therefore one of those values which justifies the imposition of relevant restrictions by public order regulations. The district council is the competent authority for these matters.

Considering the necessity of a quick response to a threat and the inability of immediate proceeding by the district council, Article 42 paragraph 2 ADG allows the district board, in case of urgency, to issue district public order regulations. In this case, the following two conditions must be met cumulatively: 1) lack of adequate regulation; 2) need to protect the values indicated in Article 41 paragraph 1 ADG.

In view of the fact that the district council is a legislative authority, the legislators in Article 42 paragraph 3 ADG provided for the institution of approval of public order regulations adopted by the district government. District public order regulations are therefore subject to approval at the next session of the district council. They shall cease to be effective if they are not submitted for approval or if they are refused to be approved, the time limit for determining the loss of force being specified by the district council.

District public order regulations apply in municipalities of the district concerned, so it is important to ensure widespread dissemination of relevant information there. Therefore, Article 42 paragraph 4 ADG obliges the district governor to send this information to executive bodies of the municipalities located in the district area and to governors of the neighbouring districts the next day after the adoption of the regulations.

Public order regulations may be adopted by a voivode and the central government administration not integrated within the region, while the provincial government does not have this kind of legislative power. ${ }^{38}$

The legislature has entrusted local and regional government with a number of responsibilities related to ensuring security. It is this territorial structure that knows best the needs of its inhabitants and is thus best prepared to meet those needs. However, it does not always have the power and resources to do so. This is particularly evident in the case of heightened threats of considerable dynamism. It should be

${ }^{37}$ Article 41 paragraph 1 of the Act of 5 June 1998 on District Government (consolidated text: Journal of Laws of 2017, item 1868, as amended), hereinafter: ADG. See also: M. Karpiuk, "Akty prawa miejscowego organów samorządu terytorialnego", [in:] Legislacja administracyjna, ed. M. Karpiuk et al., Warszawa 2013, p. 121.

38 See also M. Czuryk, M. Karpiuk, M. Mazuryk, eds., Ustawa o wojewodzie i administracji rzadowej w województwie. Komentarz, Warszawa 2012, pp. 161-133; M. Karpiuk, "Działalność prawodawcza administracji rządowej”, [in:] Akty normatywne i administracyjne, ed. M. Karpiuk, Warszawa 2009, pp. 85-86; P. Szreniawski, "Pozycja prawna organów rządowej administracji niezespolonej", [in:] Niezespolona administracja rządowa, eds. M. Czuryk, M. Karpiuk, J. Kostrubiec, Warszawa 2011, p. 21; M. Karpiuk, "Status prawny terenowych organów administracji rządowej w sferze bezpieczeństwa publicznego", [in:] Prawo bezpieczeństwa publicznego, eds. M. Karpiuk, K. Walczuk, Warszawa 2013, p. 89; M. Karpiuk, J. Kostrubiec, "The Voivodeship Governor's role in health safety", Studia Iuridica Lublinensia 27, 2018, no. 2. 
stressed that tasks related to ensuring public security are both expensive and require specialist equipment and personnel resources, which is why the local and regional government is not capable of fulfilling them, and as a result they must fall within the responsibilities of central government bodies. An important aspect of the implementation of public security protection tasks is the institution of cooperation, which both serves better effectiveness and the quality and speed of response to a threat, the effects of which may in time prove considerable. In view of the above, greater emphasis should be put on this cooperation, both with public and private entities.

\section{Bibliography}

Czuryk M., “Akty prawa miejscowego organów rządowej administracji niezespolonej”, [in:] Niezespolona administracja rzadowa, eds. M. Czuryk, M. Karpiuk, J. Kostrubiec, Warszawa 2011.

Czuryk M., "Podstawy normatywne wprowadzenia, obowiązywania oraz zniesienia stanu wojennego", [in:] Prawo obronne Rzeczypospolitej Polskiej w zarysie, eds. M. Czuryk, W. Kitler, Warszawa 2014.

Czuryk M., "Podstawy prawne bezpieczeństwa narodowego w stanie kryzysu i wojny", Roczniki Nauk Społecznych 2013, no. 3.

Czuryk M., "Prawne podstawy bezpieczeństwa narodowego", [in:] Podstawy bezpieczeństwa wspótczesnego państwa (podmiotu). Implikacje, ed. J. Pawłowski, Warszawa 2015.

Czuryk M., "Stanowienie aktów prawa miejscowego przez organy samorządu terytorialnego szczebla lokalnego i regionalnego", [in:] Akty normatywne i administracyjne, ed. M. Karpiuk, Warszawa 2009.

Czuryk M., "Właściwość Rady Ministrów oraz Prezesa Rady Ministrów w zakresie obronności, bezpieczeństwa i porządku publicznego", [in:] System Bezpieczeństwa Narodowego, vol. 3, ed. M. Karpiuk, Olsztyn 2017.

Czuryk M., "Zadania i kompetencje samorządu terytorialnego w zakresie zarządzania kryzysowego", [in:] Zadania i kompetencje samorzadu terytorialnego $w$ zakresie porzadku publicznego i bezpieczeństwa obywateli, obronności oraz ochrony przeciwpożarowej i przeciwpowodziowej, eds. M. Karpiuk, M. Mazuryk, I. Wieczorek, Łódź 2017.

Czuryk M., "Zadania organów jednostek samorządu terytorialnego w stanie klęski żywiołowej”, Zeszyty Naukowe AON 2009, no. 3.

Czuryk M., Dunaj K., Karpiuk M., Prokop K., Bezpieczeństwo państwa. Zagadnienia prawne i administracyjne, Olsztyn 2016.

Czuryk M., Dunaj K., Karpiuk M., Prokop K., Prawo zarzadzania kryzysowego. Zarys systemu, Olsztyn 2016.

Czuryk M., Karpiuk M., Mazuryk M., eds., Ustawa o wojewodzie i administracji rzadowej w województwie. Komentarz, Warszawa 2012.

Dunaj K., "Kompetencje Prezydenta RP w sprawach obronności i bezpieczeństwa państwa", [in:] Rozważania nad problemami współczesnych społeczeństw demokratycznych, Płock 2010.

Dunaj K., "Konstytucyjna regulacja samorządu terytorialnego w wybranych państwach Unii Europejskiej”, [in:] Samorząd terytorialny w procesie integracji europejskiej, ed. K. Dunaj, Łomża 2015.

Dunaj K., "Zadania i kompetencje Rady Ministrów w sferze obronności i bezpieczeństwa państwa", [in:] Wspótczesne bezpieczeństwo narodowe i międzynarodowe. Uwarunkowania, relacje, zależności, vol. 1, eds. M. Kubiak, M. Minkina, Siedlce 2011. 
Karpiuk M., “Akty prawa miejscowego organów samorządu terytorialnego”, [in:] Legislacja administracyjna, eds. M. Karpiuk, J. Kostrubiec, M. Paździor, K. Popik-Chorąży, K. Sikora,Warszawa 2013.

Karpiuk M., "Bezpieczeństwo jako instytucja konstytucyjna. Zarys problematyki”, [in:] Wybrane problemy bezpieczeństwa globalnego po zimnej wojnie, ed. W. Gizicki, Lublin 2015.

Karpiuk M., "Działalność prawodawcza administracji rządowej”, [in:] Akty normatywne i administracyjne, ed. M. Karpiuk, Warszawa 2009.

Karpiuk M., "Działanie organów administracji publicznej w czasie stanów nadzwyczajnych", Studia Prawnicze i Administracyjne 2015, no. 4.

Karpiuk M., "Konstytucyjna właściwość Sejmu w zakresie bezpieczeństwa państwa", Studia Iuridica Lublinensia 2017, no. 4.

Karpiuk M., Ksztaltowanie się instytucji stanów nadzwyczajnych w Polsce, Warszawa 2013.

Karpiuk M., Miejsce samorządu terytorialnego w przestrzeni bezpieczeństwa narodowego, Warszawa 2014.

Karpiuk M., "Normatywne uwarunkowania stanu wojennego i wyjątkowego", Studia Prawnicze i Administracyjne 2015, no. 3.

Karpiuk M., "Prawne podstawy bezpieczeństwa", [in:] Podstawowe kategorie bezpieczeństwa narodowego, eds. A. Żukowski, M. Hartliński, W.T. Modzelewski, J. Więcławski, Olsztyn 2015.

Karpiuk M., "Prezydent Rzeczypospolitej Polskiej jako organ stojący na straży bezpieczeństwa państwa", Zeszyty Naukowe AON 2009, no. 3.

Karpiuk M., "Przepisy porządkowe jako szczególny rodzaj prawa miejscowego", Studia Iuridica Lublinensia 2015, no. 4.

Karpiuk M., Samorząd terytorialny a państwo. Prawne instrumenty nadzoru nad samorządem gminnym, Lublin 2008.

Karpiuk M., "Status prawny organów samorządu terytorialnego w sferze bezpieczeństwa publicznego", [in:] Prawo bezpieczeństwa publicznego, eds. M. Karpiuk, K. Walczuk, Warszawa 2013.

Karpiuk M., "Status prawny terenowych organów administracji rządowej w sferze bezpieczeństwa publicznego", [in:] Prawo bezpieczeństwa publicznego, eds. M. Karpiuk, K. Walczuk, Warszawa 2013.

Karpiuk M., "Terenowe organy administracji publicznej właściwe w sprawach zarządzania kryzysowego", Annales Universitatis Mariae Curie-Skłodowska. Ius 2014, no. 1.

Karpiuk M., "Zadania i kompetencje Ministra Obrony Narodowej w czasie stanów nadzwyczajnych — ujęcie normatywne", [in:] Minister Obrony Narodowej i Naczelny Dowódca Sił Zbrojnych w systemie kierowania bezpieczeństwem narodowym RP. Wybrane problemy, ed. W. Kitler, Warszawa 2013.

Karpiuk M., "Zadania i kompetencje samorządu terytorialnego w czasie stanów nadzwyczajnych", [in:] Zadania i kompetencje samorzadu terytorialnego $w$ zakresie porzadku publicznego $i$ bezpieczeństwa obywateli, obronności oraz ochrony przeciwpożarowej i przeciwpowodziowej, eds. M. Karpiuk, M. Mazuryk, I. Wieczorek, Łódź 2017.

Karpiuk M., Zadania i kompetencje zespolonej administracji rzadowej w sferze bezpieczeństwa narodowego Rzeczypospolitej Polskiej. Aspekty materialne i formalne, Warszawa 2013.

Karpiuk M., "Zasady działania samorządu lokalnego w czasie stanu klęski żywiołowej”, Annales Universitatis Mariae Curie-Skłodowska. Ius 2014, no. 2.

Karpiuk M., "Zasady regulujące funkcjonowanie samorządu terytorialnego w Polsce", [in:] Samorząd terytorialny w Polsce i na Ukrainie, ed. M. Karpiuk, Poznań-Kijów 2013.

Karpiuk M., Kostrubiec J., Rechtsstatus der territorialen Selbstverwaltung in Polen, Olsztyn 2017.

Karpiuk M., Kostrubiec J., "The Voivodeship Governor's role in health safety”, Studia Iuridica Lublinensia 27, 2018, no. 2. DOI: http://dx.doi.org/10.17951/sil.2018.27.2.65.

Karpiuk M., Prokop K., Sobczyk P., Ograniczenie korzystania z wolności i praw człowieka i obywatela ze względu na bezpieczeństwo państwa i porzadek publiczny, Siedlce 2017. 
Karpiuk M., Szczęch N., Bezpieczeństwo narodowe i międzynarodowe, Olsztyn 2017.

Kitler W., Czuryk M., Karpiuk M., eds., Aspekty prawne bezpieczeństwa narodowego RP. Część ogólna, Warszawa 2013.

Kryszeń G., Prokop K., Aksjologia polskiej konstytucji, Warszawa 2017.

Prokop K., "Stany nadzwyczajne w Konstytucji RP”, [in:] Aspekty prawne bezpieczeństwa narodowego RP. Część ogólna, eds. W. Kitler, M. Czuryk, M. Karpiuk, Warszawa 2013.

Prokop K., Stany nadzwyczajne w Konstytucji Rzeczypospolitej Polskiej z dnia 2 kwietnia 1997 r., Białystok 2005.

Prokop K., "Wokół problematyki stanu klęski żywiołowej w konstytucjach państw europejskich", [in:] Studia i szkice z prawa publicznego. Księga dla uczczenia pamięci Profesora Eugeniusza Smoktunowicza, ed. A. Nowakowski, Rzeszów 2008.

Radwanowicz-Wanczewska J., Prokop K., "Organizacja systemu zarządzania kryzysowego w Polsce", [in:] Dziesięć lat reformy ustrojowej administracji publicznej w Polsce. Ogólnopolska konferencja naukowa, Lańcut, 12-14 czerwca 2008 r., eds. J. Parchomiuk, B. Ulijasz, E. Kruk, Warszawa 2009.

Szreniawski P, Obowiazek w prawie administracyjnym, Lublin 2014.

Szreniawski P., "Pozycja prawna organów rządowej administracji niezespolonej”, [in:] Niezespolona administracja rządowa, eds. M. Czuryk, M. Karpiuk, J. Kostrubiec, Warszawa 2011.

Szreniawski P., Prawno-administracyjne zagadnienia ustrojowej polityki administracyjnej, Toruń 2012.

Szreniawski P., "Samorząd terytorialny a kultura polityczna", [in:] M. Karpiuk, Samorzad terytorialny w Polsce i na Ukrainie, Poznań-Kijów 2013.

\title{
THE LEGAL STATUS OF LOCAL SELF-GOVERNMENT IN THE FIELD OF PUBLIC SECURITY
}

\section{Summary}

The vast array of responsibilities assigned to local self-government include also public security. This is all the more important as it must be ensured at every tier of administration, including in the regions. The local self-government, as the basic form of decentralised public administration, is situated closest to citizens and is therefore most responsive to their needs, with security needs being fundamental needs that must be addressed on a continuous basis.

The jurisdiction of local and regional government bodies in the field of public security concerns many areas, but it is the local government which holds most of these responsibilities while the regional government is entrusted with less responsibility in this matter. This characteristic covers the institution of emergency states, crisis management, or issuing public order regulations.

Keywords: local self-government, security.

\author{
Małgorzata Czuryk \\ czuryk@interia.pl \\ Jarosław Kostrubiec \\ j.kostrubiec@poczta.umcs.lublin.pl
}

